\title{
Inhibition of the NT-3 Receptor TrkC, Early in Chick Embryogenesis, Results in Severe Reductions in Multiple Neuronal Subpopulations in the Dorsal Root Ganglia
}

\author{
Frances Lefcort, ${ }^{1,2}$ Douglas O. Clary, ${ }^{1,3}$ Anne C. Rusoff, ${ }^{2}$ and Louis F. Reichardt ${ }^{1}$ \\ ${ }^{1}$ Howard Hughes Medical Inslilule and Department of Physiology, University of California, San Francisco, San Francisco, \\ California 94143-0724, 2Department of Biology and WAMI Medical Program, Montana State University, Bozeman, \\ Montana 59717, and 3Sugen Incorporated, Redwood City, California 94063
}

\begin{abstract}
To assess functions of neurotrophins at defined times in development, we have prepared antibodies to the extracellular domains of each of the trk receptors. Here, antibodies to trkC, the major receptor for NT-3, are used to examine trkC expression and function during the formation and maturation of the chick dorsal root ganglion (DRG). Our results show that in the immature DRG, the majority of cells express trkC, and inhibition of trkC activation results in reductions in neuronal numbers before the period of target-mediated cell death, the time when neurotrophins previously have been shown to regulate survival. Furthermore, blockade of trkC in ovo induced reductions in subpopulations of DRG neurons known to be dependent on NGF, in addition to those dependent on NT-3 during the targetregulated cell death period. An early function for NT-3 on
\end{abstract}

immature DRG neurons is supported further by data presented here that demonstrate that whereas BDNF and NGF can support a subset of immature DRG neurons in vitro, activation of the trkC receptor either by NT-3 binding or via antibodymediated cross-linking induces the most robust survival response. When all three neurotrophins are combined, the number of surviving neurons does not exceed that supported by NT-3 alone. Together, these data are consistent with coexpression of more than one trk receptor family member on immature sensory neurons, and they demonstrate that inhibition of trkC activation has surprisingly early and pleiotrophic effects on the development of spinal sensory ganglia.

Key words: trkC receptor; neurotrophin-3; DRG; chicken; differentiation; antibody blockade
Investigations of the effects of neurotrophins and their receptors, the trk family of tyrosine kinases and p $75^{\text {NGFR }}$ (Snider, 1994), on the developing dorsal root ganglion (DRG) (Scott, 1992) have contributed significantly to our understanding of their function during embryogenesis. In the course of differentiation into mature sensory neurons, DRG neurons develop distinct neurotrophin dependencies. The majority of the cutaneous afferents express the NGF receptor trkA and are NGF-dependent during the period of target-mediated cell death (for review, see Snider, 1994). In contrast, the vast majority of muscle proprioceptive afferents are larger in diameter, express trkC, and are trophically dependent on NT-3 (Hory-Lee et al., 1993; Klein et al., 1994; Lopresti and Scott, 1994; Oakley et al., 1995). In the chick, this latter population resides predominantly in the ventrolateral (VL) portion of the ganglion, whereas the former resides overwhelmingly in the dorsomedial (DM) sector of the ganglion (Lefcort et al., 1993, 1994; Kahane and Kalcheim, 1994; Zhang et al., 1994; Oakley et al., 1995).

Understanding how growth factors function to sculpt the formation of the nervous system is of key biological interest. The study of one particular family of neuroactive factors, the neuro-

\footnotetext{
Received Dec. 6, 1995; revised March 5, 1996; accepted March 7, 1996.

This work was supported by the Howard Hughes Medical Institute, Experimental Program to Stimulate Competitive Research (EPSCOR) (F.L.), and an American Cancer Society Institutional Research Grant (F.L.). We thank Drs. I. Farinas, S. Figer, and H. Lefcort for helpful discussions; Dr. Andre Brandli for collaborating in the design of PCR primers; C. Backus, X. Wang, and S. Hapner for technical assistance; and Genentech for generously providing BDNF and NT-3.

Correspondence should be addressed to Dr. Frances Lefcort, Department of Biology, Montana State University, Bozeman, MT 59717.

Copyright $(1996$ Society for Neuroscience $0270-6474 / 96 / 163704-10 \$ 05.00 / 0$
}

trophins, whose members include NGF, brain-derived neurotrophic factor (BDNF), and neurotrophin-3 (NT-3), -4/5, and -6 (for review, see Bothwell, 1995), has pointed to the crucial role these factors play during the development of the nervous system in protecting postmitotic neurons from programmed cell death.

In addition to their role in target-regulated programmed cell death, numerous in vitro studies during the past few years have demonstrated activities for neurotrophins, in particular NT-3, in events occurring before target innervation (Davies, 1994). For example, NT-3 has been shown to induce proliferation of neural crest cells (Kalcheim et al., 1992; Chalazonitis et al., 1994) and DRG neuronal precursor cells (Memberg and Hall, 1995), to promote the survival of sympathetic neuroblasts before their dependence on NGF (Birren et al., 1993; DiCicco-Bloom et al. 1993), and to promote neuronal differentiation (Wright et al., 1992; Pinco et al., 1993). In light of the numerous functions in which they have been implicated, it is important to identify the steps in DRG development in vivo in which neurotrophins might be involved, such as migration and proliferation of the neural crest, survival and maturation of DRG precursor cells, and neuronal differentiation, in addition to their classical role in targetmediated cell death.

To evaluate the roles of neurotrophins, it is useful to control both spatially and temporally the timing of application of reagents that inhibit their functions. Although it may become possible to do this in mice, using regulative gene deletion, at present the most feasible approach is the use of function-inhibitory antibodies. Thus, we have isolated cDNAs for the avian trkC receptor (Lefcort et al., 1993, 1994), expressed and purified its extracellular domain, and generated a highly specific function-perturbing anti- 
body. Results in the present article show that trkC is expressed by the majority of immature DRG neurons and in vitro can act as the functionally predominant, identified trk receptor. Furthermore, injections of monovalent anti-trkC Fabs in ovo result in major deficits in both the VL and DM subpopulations, with half of this reduction occurring before the onset of target-mediated programmed cell death. Thus, NT-3 has multiple functions during development of the DRG. In addition to regulating programmed cell death of the VL population, it also is essential for normal development of many DM neurons that later depend on other neurotrophins. Together these data point to an early, significant role for NT-3 and trkC in the development of the avian DRG.

\section{MATERIALS AND METHODS}

Isolation of avian trkC clones and generation of anti-trkC antibody. Fragments of the avian homolog of $t r k C$ were generated by PCR by amplifying cDNA prepared from embryonic day 9 (E9) DRGs using oligonucleotide primers specific for the trk family tyrosine kinase domain: 5' GGGTCTAGAT(TC)GA(AG)AA(TC)CC(AGCT)CA(AG)TA 3', approximatcly corresponding to amino acid 485 in human trkA, and 5' GGGAATTCCCTC (AGCT) C(TG)(TC)TGCCA(AG)CA(AGCT)CC 3', approximately corresponding to amino acid 762 in human trkA. PCR buffer conditions were those recommended by the manufacturer (Perkin-Elmer Cetus, Norwalk, CT). These cloned fragments then were used to probe an E8 chick DRG library prepared in the plasmid vector CDM8. Among the clones isolated was one full-length cDNA, clone 1201. Because we intended to express the entire extracellular domain of chicken trkC as a recombinant protein, we used the PCR technique to amplify the DNA sequence from the initiator methionine to the start of the transmembrane domain. The 3' oligonucleotide primer also contained DNA sequences encoding an antibody epitope derived from c-myc and a polyhistidine sequence (single-letter amino acid code: GEQKLISEEDLHHHHHH) followed by a stop codon. This modified DNA sequence was cloned into a replicating COS cell expression vector, pMT23. Transfection of COS7 cells with this construct resulted in the production and secretion of a $\sim 90$ $\mathrm{kDa}$ protein that could be recognized by immunoblot using an mAb recognizing the epitope tag (9E10; Evan et al., 1985). This fragment of the trkC receptor was purified from the medium by sequential chromatography on wheat germ agglutinin-agarose (Pharmacia LKB, Piscataway, NJ), a His-Bind nickel-chelating column (Novagen, Madison, WI), and ion-exchange chromatography on Mono Q (Pharmacia LKB). Rabbit polyclonal antisera were raised to the purified extracellular domain of the avian trkC receptor (Caltag Laboratories, Healdsburg, CA), and IgG and Fab fragments were prepared by standard procedures (Harlow and Lane, 1988).

$D R G$ cell cultures. DRGs from $\mathrm{E} 7.5 / \mathrm{E} 8$ chick embryos were dissected in HBSS (calcium and magnesium free) and incubated in trypsin $(0.1 \%$, Worthington, Freehold, NJ) for $5 \mathrm{~min}$ at $37^{\circ} \mathrm{C}$. The cells were preplated for $1 \mathrm{hr}$ on tissuc-culture plastic to enrich for neurons. The nonadherent population (mostly neurons) was then replated on tissue-culture plastic coated with laminin $(5 \mu \mathrm{g} / \mathrm{ml})$ and cultured overnight in F12 supplemented with penicillin and streptomycin and $0.4 \mathrm{mg} / \mathrm{ml} \mathrm{BSA} \mathrm{(A7638,}$ Sigma, St. Louis, MO). Neurotrophins $(5-10 \mathrm{ng} / \mathrm{ml}$ ) and/or anti-trkC (CTC) IgG, nonimmune IgG (Cappel Laboratories, Durham, NC), or Fab fragments were then added to some of the wells. BDNF and NT-3 were kindly provided by Genentech (South San Francisco, CA). Cells were cultured for $48 \mathrm{hr}$ and then fixed in $3 \%$ paraformaldehyde and $1 \%$ glutaraldehyde in PBS for $15 \mathrm{~min}$. In some experiments, DRGs were removed from embryos at E4.5 (St.25). Those DRG were treated as above except that once dissociated, the cells did not undergo a preplating step and were cultured for only $24 \mathrm{hr}$. The total number of neurons (defined as bearing a neurite at least two cell diameters in length) was detcrmincd in each well. All conditions were tested in duplicate or triplicate as specified. To compare the effects of density on cell survival, the number of cells plated per well varied, between experiments, from 1000 to 4000 cells. Thus, to standardize the results, the number of surviving neurons relative to the number supported by NT-3 was determined for each condition in each experiment.

In ovo injections and quantitation of DRG cell numbers. Beginning at St.18/19 (E2.75), White Leghorn eggs were windowed, and embryos received daily injections of $30-60 \mu \mathrm{g}$ of anti-chick trkC (CTC) Fab fragments or nonimmune rabbit Fab fragments (prepared in the same manner as the CTC Fabs or purchased from Cappel). Half of the Fabs were injected into the base of the right wing bud, and half were injected into the amniotic cavity near the wing bud or onto the chorioallantoic membrane (beginning on E4). Embryos were fixed in Carnoy's fixative (60\% ethanol, $30 \%$ chloroform, $10 \%$ acetic acid), at either E4.5/5 (St.25/ 26) or E7/7.5, embedded in paraffin, and serially sectioned at $7 \mu \mathrm{m}$. Scetions were then stained in $0.1 \%$ cresyl violet, and neurons with a clear nucleolus in every sixth section of brachial ganglion 14 were counted. For the younger animals, E4/5, it was not possible to distinguish neurons unambiguously (which when immature have elongated nuclei similar to Schwann cells); therefore, all cells with a clear nucleolus were counted. To determine the percentage of trkC-positive cells at E4/4.5 and E7.5, embryos were fixed in paraformaldehyde and serial-sectioned at $10 \mu \mathrm{m}$. Slides were processed for trkC immunolabeling (see below) and then counterstained with cresyl violet. All cells unambiguously labeled with the trkC antibody were counted in every fourth section through brachial ganglion 14. At E7.5, a population of faintly trkC-positive cells exist at the extreme DM pole of the ganglion. These cells were not counted given that their intensity was considerably less than the brightly labeled cells in the VL portion of the ganglion and that their recognition varied depending on the immunocytochemical conditions used.

Immunocytochemistry. Embryos from E2 to E7.5 were fixed in $4 \%$ paraformaldehyde or Carnoy's fixative for $2 \mathrm{hr}$ to overnight (depending on the age), cryoprotected overnight in $30 \%$ sucrose in PBS, and cryosectioned in OCT (Miles). Before cryosectioning, some of the embryos were incubated overnight in at 1:1 mixture of $30 \%$ sucrose in PBS and OCT. Endogenous peroxidase activity was quenched by incubating the sections in TBS (10 mM Tris, $\mathrm{pH} 7.4,150 \mathrm{~mm} \mathrm{NaCl}$ ) containing $3 \%$ hydrogen peroxide and $10 \%$ methanol for 15 min. Subsequently, the sections were incubated for $1 \mathrm{hr}$ at room temperature in a blocking buffer composed of TBS containing $10 \%$ normal goat serum, $1 \%$ glycine, and $0.2 \%$ 'rriton $\mathrm{X}-100$. 'The sections were incubated at $4^{\circ} \mathrm{C}$ overnight in primary antibodics $(1 \mu \mathrm{g} / \mathrm{ml})$, diluted in the blocking buffer. Immunoreactivity was detected using a Vectastain Elite ABC-peroxidase kit (Vector Laboratories, Burlingame, CA). Development was conducted in the presence of $0.05 \%$ diaminobenzidine tetrahydrochloride and $0.003 \%$ hydrogen peroxide. Some of the slides were then counterstained in cresyl violet before they were coverslipped.

Transfections. Human embryo kidney 293 cells were plated on polylysine-coated chamber slides and transiently transfected with cDNAs encoding full-length avian $\operatorname{tr} k A, B$, or $C$ that had been purified on a solid-phase anion-exchange resin (Qiagen 12145; Qiagen, Chatsworth, (A), according to the instructions of the manufacturer, or they were mock-transfected with lipofectamine (Gibco BRL, Gaithersburg, MD), according to the instructions of the manufacturer. Cultures were fixed after $24 \mathrm{hr}$ with $4 \%$ paraformaldehyde in PBS and stained as above except that the secondary antibody was a fluorescein-conjugated goat anti-rabbit IgG (Southern Biotechnology Associates, Birmingham, AL). For immunoblot analysis, COS7 cells were transfected as above and lysed as described (Clary et al., 1994). Trk proteins were concentrated by immunoprecipitation with an antibody that recognizes the cytoplasmic tails of all three trk receptors (Clary et al., 1994). The immunoprecipitates were then blotted with either an antibody recognizing the cytoplasmic tails or the anti-trkC antibody, C"lC:

\section{RESULTS}

\section{Specificity of the anti-trkC antibody}

The specificity of the chick trkC polyclonal antibody (CTC pAb) was determined using several approaches (Figs. 1-3). By immunoblot, CTC $\mathrm{pAb}$ did not recognize avian trkA or B expressed by transfected COS7 cells but did react with a protein of $\sim 130 \mathrm{kDa}$ expressed by COS7 cells transfected with a full-length avian $t r k C$ cDNA (Fig. 1A). This is in the expected molecular weight range for full-length chick trkC. Further evidence of the specificity of CTC $\mathrm{pAb}$ for trkC and its lack of cross-reactivity with the other trk family members was provided by immunocytochemical analysis of HEK 293 cells expressing trkA, B, or C (Fig. 1B). As in immunoblots, the CTC pAb labels only 293 cells transfected with avian trkC and does not react with proteins expressed by 293 cells transfected with avian trk $A$ or $t r k B$. Expression of trkA and trkB in 


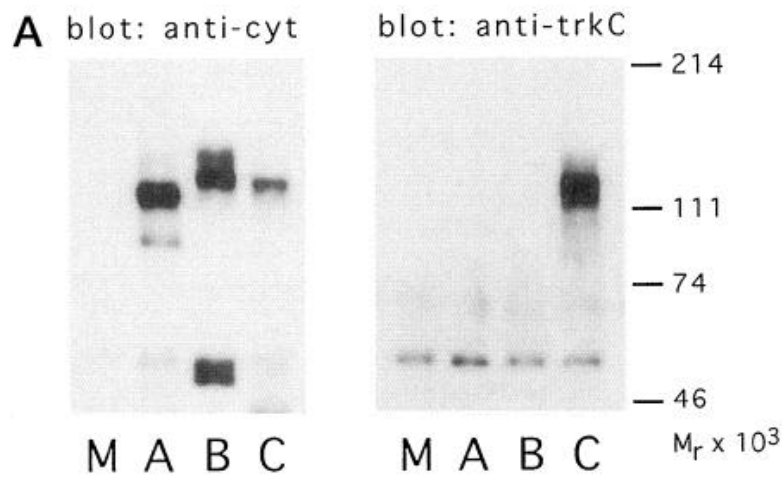

Transfection

B mock

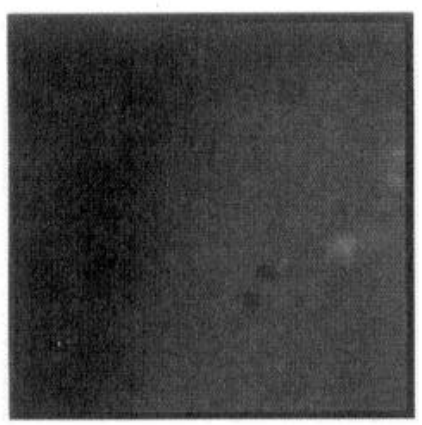

trkA

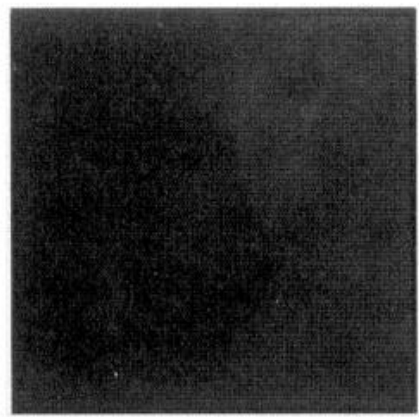

trkB

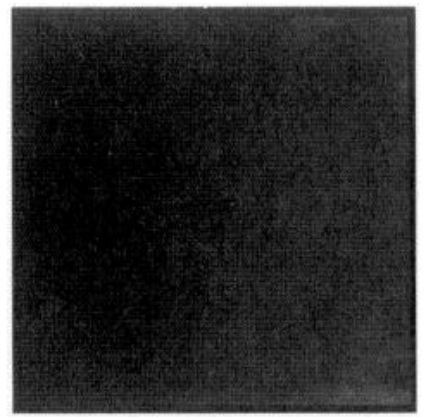

trkC

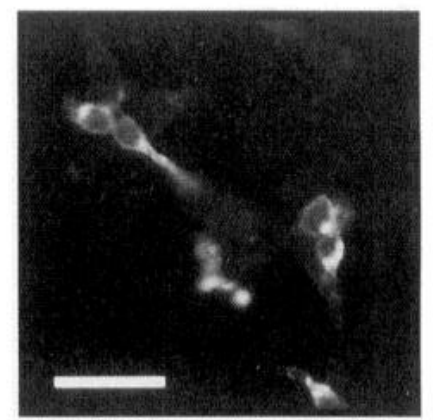

Figure 1. $A$, Specificity of the CTC anti-trkC antibody: immunoblotting. COS7 cells were transfected with chick trkA $(A)$, trkB $(B)$, or trkC $(C)$, or were mock-transfected $(M)$, and lysates prepared from the transfected cells were immunoprecipitated with an antibody recognizing the cytoplasmic tail of all three trk receptors. The immunoprecipitates were immunoblotted with either the antibody that recognizes the trk cytoplasmic tail (left) or with the CTC anti-trkC antibody (right). B, Specificity of the CTC anti-trkC antibody: immunostaining. HEK293 cells were transiently transfected with chick trkA, trkB, or $t r k C$, or were mock-transfected (mock). The cells were then immunostained with the CTC anti-trkC antibody. Parallel transfections stained with antibodies recognizing chick trkA and chick trkB demonstrated abundant expression of those receptors (data not shown). Scale bar, $50 \mu \mathrm{m}$.

these two experiments was confirmed with antibodies that specifically recognize avian trkA and trkB (Lefcort et al., 1993, 1994).

\section{Functional activities of the CTC pAb: monovalent versus bivalent IgG fractions}

To determine whether the CTC pAb was capable of perturbing the interaction between trkC and its ligand NT-3, dissociated E7/E8 DRG neurons were cultured in the presence of neurotrophins with or without Fab fragments of the CTC pAb (Fig. 2). After $48 \mathrm{hr}$ in vitro, the number of surviving neurons cultured in the presence of NT-3 and the monovalent CTC Fabs was dramatically reduced relative to wells containing NT-3 alone or NT-3 and a nonimmune rabbit Fab fraction (Fig. $2 A$ ). Only $\sim 9 \%$ of those cells plated in the presence of NT-3 and the CTC Fabs survived; this compares with $6 \%$ survival in the absence of neurotrophin. Those cells that survived tended to be small-diameter neurons and may represent newly differentiated neurons, which have been shown previously to be neurotrophin-independent (Ernsberger and Rohrer, 1988; Wright et al., 1992). Thus, these data indicate that the CTC Fab fragments can successfully block the biological activities of NT-3 on these neurons. To characterize further the specificity of the anti-trkC Fabs, we determined whether they would interfere with the trophic activities of NGF or BDNF on DRG neurons in vitro (Fig. $2 B$ ). All three neurotrophins support discrete subpopulations of DRG neurons cultured in vitro (HoryLee et al., 1993; Lopresti and Scott, 1994). Results in Figure 2B show that the CTC Fabs did dramatically reduce the survival of the NT3-promoted DRG subpopulation, but had no inhibitory effect on the ability of NGF or BDNF to support survival of DRG neurons. Thus the CTC Fabs prevent ligand-mediated activation of trkC but not trkA or trkB.

In contrast to results using monovalent CTC Fabs, results summarized in Figure $2 C$ show that bivalent CTC IgG promotes survival of DRG neurons in vitro in the absence of any exogenously supplied neurotrophin. In fact, culture in the presence of CTC bivalent IgG alone is almost as effective as NT-3 in promoting the survival and outgrowth of DRG neurons in vitro. Thus, presumably by inducing oligomerization of trkC receptors, the CTC pAb bivalent IgGs directly activate trkC. These results argue that activation of trkC is sufficient for the promotion of survival and outgrowth of a subpopulation of DRG neurons and that activation of other receptors, such as $\mathrm{p} 75^{\mathrm{NGFR}}$, is not required. Similar observations have been made with bivalent anti-rat trkA IgG on neonatal rat sympathetic neurons (Clary et al., 1994).

\section{TrkC expression throughout the genesis of the DRG}

As a first step toward understanding the function of trkC in the differentiation of the DRG in vivo, we determined its spatial and temporal patterns of expression throughout the genesis of the DRG (Fig. 3). The first identifiable precursor cells that will generate DRG neurons are neural crest cells, which bud from the dorsal margins of the invaginating neural tube to migrate ventrolaterally to give rise to the majority of the peripheral nervous system (for review, see Bronner-Fraser, 1994). Thus, the first time point at which we examined for expression of trkC was St.19/20, which corresponds to the end of neural crest migration in the 

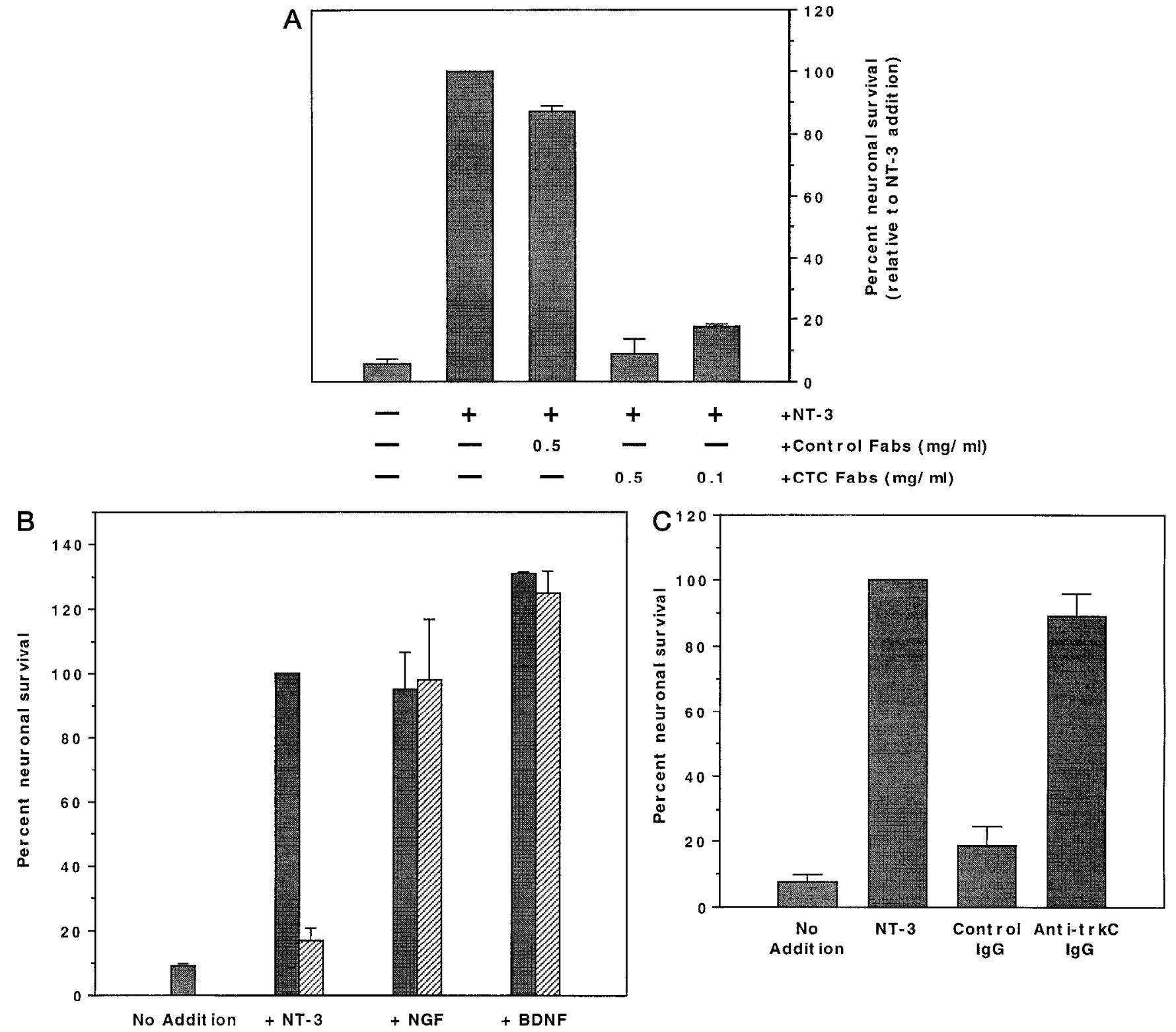

Figure 2. A, NT-3-promoted survival of DRG neurons in vitro is blocked by anti-trkC Fabs. Neurons were cultured in the presence of NT-3 (5 ng/ml), alone or in the presence of either anti-trkC Fabs (CTC Fabs: 100 or $500 \mu \mathrm{g} / \mathrm{ml}$ ) or a nonimmune Fab preparation. The total number of surviving cells with neurites was counted after $48 \mathrm{hr}$. Results are expressed as the mean (relative to NT-3) \pm SEM of duplicate cultures from four separate experiments. $B$, Anti-trkC Fahs do not block NGF- or BDNF-promoted survival of DRG neurons. Neurons were cultured in the presence of either NGF, BDNF, or NT-3 (all at $5 \mu \mathrm{g} / \mathrm{ml}$ ) and in the absence or presence of anti-trkC Fabs $(500 \mu \mathrm{g} / \mathrm{ml})$. After $48 \mathrm{hr}$, the number of surviving neurons with neurites was determined. Results are expressed as the mean (relative to NT-3) \pm SEM of duplicate cultures from three separate experiments and in the absence (dark gray bars) or presence (bars with diagonal lines) of anti-trkC Fabs. $C$, Bivalent IgG preparations of anti-trkC promote survival and outgrowth of DRG neurons in vitro. Neurons from E7/8 DRG were cultured in either the presence of NT-3 or anti-trkC IgG or nonimmune rabbit IgG. After $48 \mathrm{hr}$, the number of surviving neurons with neurites was determined. Data are expressed as the mean (relative to NT-3) \pm the SEM of three separate experiments conducted in duplicate.

trunk region (Tosney, 1978; Lallier and Bronner-Fraser, 1988). Adjacent sections were stained with a general neural crest marker, HNK-1 (Fig. 3A), and the CTC pAb (Fig. 3B). Comparison of the two panels shows that only a small subset of the migrating neural crest cells expressed trkC receptor. Some of the trkC-expressing cells had a distinct neuronal morphology (albeit that of an immature bipolar neuron), while others appeared very flat and irregularly shaped, morphologically reminiscent of neural crest cells cultured in vitro (examples in Fig. $3 C, D$ ).

By St.22/23, the DRGs have become morphologically distinct and consist of a discrete aggregate of cells (Lallier and Bronner-
Fraser, 1988). Results using the CTC pAb show that at this early stage, trkC is expressed in many but not all cells within this immature DRG (Fig. 3E). Within $1 \mathrm{~d}(\mathrm{E} 4 / \mathrm{E} 4.5=$ St.24/25), the vast majority of the cells within all regions of the DRG seem to express trkC (Fig. 3F). By St.32 (E7.5/8, Fig. 3G), prominent staining of the Golgi makes trkC-expressing cells easily distinguishable: they now reside primarily in the $\mathrm{VL}$ region of the ganglion. These cells are the large-diameter neurons (Hamburger et al., 1981) that comprise part of the NT-3-dependent population in vitro (Hory-Lee et al., 1993) and in vivo (Oakley et al., 1995). In addition, faint trkC expression can be observed on a population of 

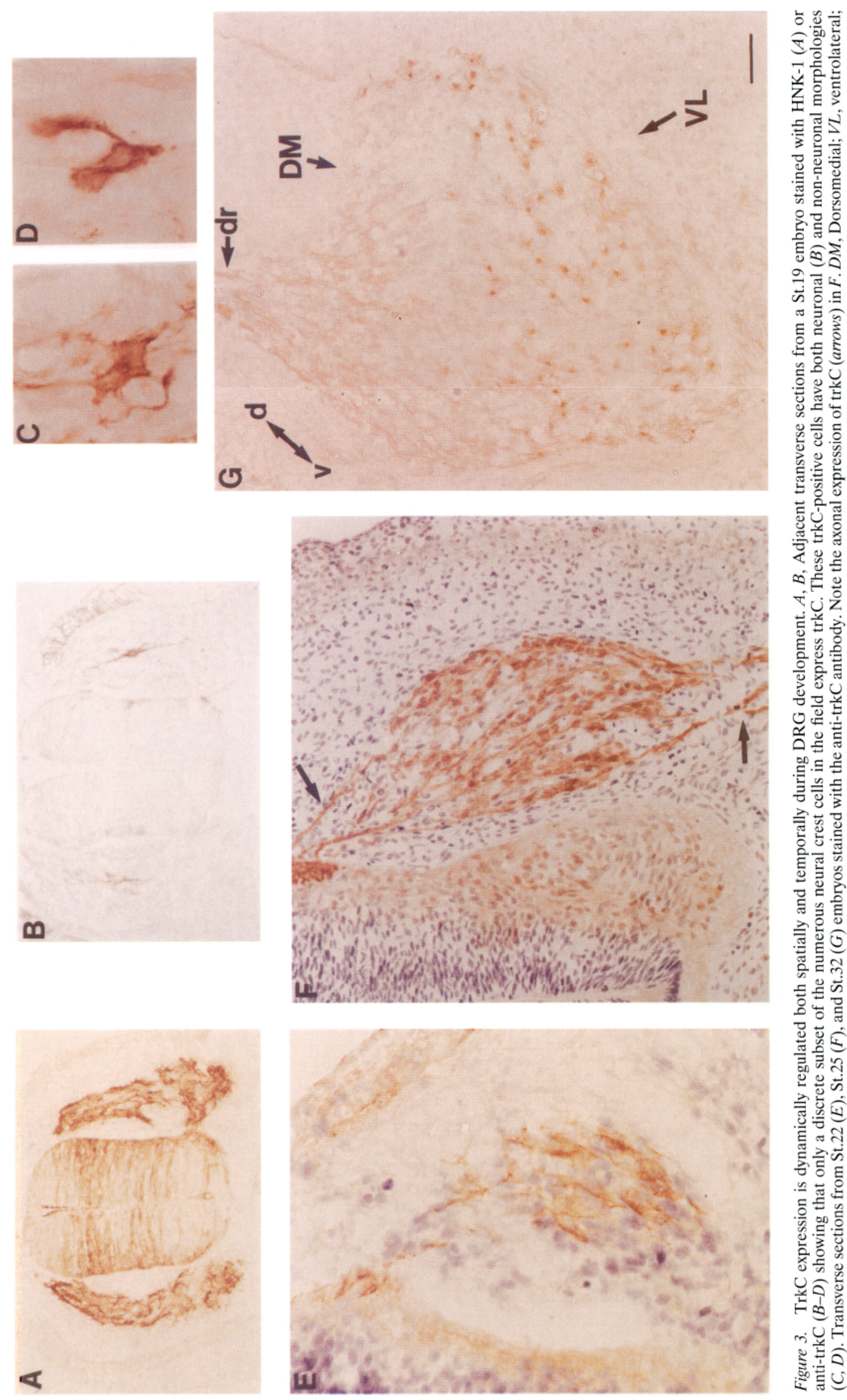

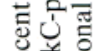

要者

\&

$\infty$

एنं

咅离

흥

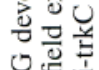

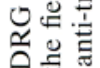

몰 ․ㅗ

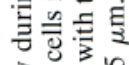

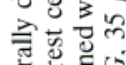

政

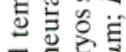

空蒫

준

然它

कि है

害骂

政

m

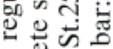

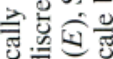

赵

줄

을

동

5.

중

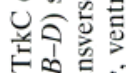

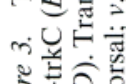

ํ.

客言讨 


\begin{tabular}{lcc}
$\begin{array}{l}\text { Table 1. Percentage of trkC-positive cells in E4.5 and E7.5 dorsal root } \\
\text { ganglia }\end{array}$ \\
\hline E4.5 & $63 \pm 7 \%$ & $n=3$ \\
E7.5 & $20 \pm 4 \%$ & $n=3$ \\
\hline
\end{tabular}

All cells strongly cxpressing trkC werc counted in scrial sections of brachial ganglion 14 (see Materials and Methods).

small-diameter cells at the extreme DM pole of the ganglion (not shown; see Kahane and Kalcheim, 1994). Because neurogenesis and differentiation are ongoing in this region of the ganglion at this time (Carr and Simpson, 1978), these cells may be nascent, immature neurons. By this time, E7.5, the period of programmed cell death for the large-diameter VL-located population is well underway, having begun at circa E4.5/5 (Carr and Simpson, 1978; Hamburger et al., 1981). To quantify these changes, we determined the number of trkC-positive cells at E4.5 and E7.5. Results shown in Table 1 demonstrate that $\sim 63 \%$ of the cells in immature DRG express trkC. Neurons and non-neuronal cells cannot be distinguished morphologically at this stage, but there are essentially no non-neuronal cells in the DRG at this early stage (Carr and Simpson, 1978; Bhattacharyya et al., 1991). Moreover, the trkC signal cannot be attributed to Schwann cells because one does not see trkC-immunoreactive cells in developing ventral roots (E3-E6; Fig. 3), nor has mRNA for trkC been localized over Schwann cells (Zhang et al., 1994). Thus, the vast majority, if not all, of the cells expressing trkC must be neurons or neural precursor cells. This number decreases to $\sim 20 \%$ strongly trkCpositive neurons by E7.5. Thus, over the course of differentiation of the DRG, the pattern of trkC expression changes dramatically both temporally and spatially from rare expression in migrating neural crest to a broad, widespread expression in the immature DRG, to a more restricted pattern of expression later in development during the process of target-mediated cell death. These expression patterns of trkC protein confirm previously reported in situ hybridization patterns for avian $t r k C$ mRNA (Williams et al., 1993; Kahane and Kalcheim, 1994; Zhang et al., 1994) and extend those data by providing high resolution cellular information, including demonstration of axonal expression of trkC (Fig. $3 F$, arrows).

\section{In ovo effects of the anti-trkC Fab fragments on the development of the DRG}

To determine roles of trkC during DRG development, we made daily injections of the blocking CTC Fab fragments into embryos beginning at St.18, and then fixed the embryos at St.31 (E7/E7.5). St.18 corresponds to the near completion of neural crest migration in the brachial region and St.31/32 corresponds to the completion of the bulk of cell death for the large, VL population of DRG neurons in the brachial region (Carr and Simpson, 1978; Hamburger et al., 1981). Control embryos were injected with a Fab preparation made from a nonimmune rabbit serum. Results in Table 2 show that treatment with the anti-trkC Fab preparation results in a $47 \%$ reduction in the number of DRG neurons ( $p \leq$ $0.005)$. Sections through the center of an experimental and control DRG are shown in Figure 4. The DRG at this stage can be divided into two distinct subpopulations: a small-diameter, DM population and a larger-diameter, VL population, each with distinct neurotrophin dependency and functional projections (for review, see Scott, 1992). Therefore, we also counted neurons in each of those subpopulations. As expected from in vitro studies, we found that the greatest deficit after treatment with the anti-trkC Fab
Table 2. Number of DRG neurons after antibody treatment

\begin{tabular}{lllll}
\multicolumn{1}{c}{ Nonimmune Fab } & Anti-trkC Fab & $\begin{array}{c}\text { Reduction } \\
(\%)\end{array}$ \\
\hline St.31 & & & & \\
(E7-7.5) & & 47 & $p \leq 0.005$ \\
Total & $8538 \pm 916(n=3)$ & $4486 \pm 543(n=4)$ & 77 & $p \leq 0.02$ \\
VL & $2246 \pm 727$ & $516 \pm 84$ & 36 & $p \leq 0.01$ \\
DM & $6292 \pm 289$ & $3970 \pm 564$ & & \\
St.26 & & & & \\
(E5) & & & 27 & $p \leq 0.02$ \\
Total & $4045 \pm 254(n=4)$ & $2933 \pm 365(n=4)$ &
\end{tabular}

For the older embryos (E7/E7.5) all neurons were counted in every sixth section of brachial ganglion 14. VL-and DM-located neurons could be distinguished at this age on the basis of location and diameter (see Materials and Methods). Significance levels were detcrmined by the onc-tailed Student's $t$ test.

fragments was in the large-diameter VL population of neurons, with a deficit of $77 \%(p \leq 0.02)$; however, the small-diameter, DM-located population of neurons also underwent a reduction of $36 \%(p \leq 0.01)$. The potential significance of these data will be discussed below.

\section{Early effects of anti-trkC Fab fragments on DRG development}

The deficit at E7/7.5, induced by injection of anti-trkC Fab fragments, in the number of the DM DRG neurons, a group of neurons that when cultured at E7-9 are NGF-dependent and express trkA (Lefcort et al., 1993), coupled with the early widespread expression of trkC in the DRG (Fig. 3), indicated that interactions between trkC and its ligand(s) might play an important role during the early differentiative events occurring within the DRG, before the period of postmitotic, target-mediated neuronal cell death. To test that possibility, embryos were examined at St.26 (E4.5/5), which coincides with the very onset of postmitotic cell death in the DRG. A reduction of $27 \%$ in cell number could be induced by incubation in ovo with the anti-trkC Fab preparation ( $p \leq 0.02$; Table 2 ). This number may be an underestimate of the actual reduction in the mature neuronal population; it is difficult to distinguish postmitotic neurons definitively from neuroblasts or non-neuronal cells at this early stage, and therefore total cell numbers rather than neuronal populations were determined. Because non-neuronal cells are not observed in the brachial DRG until E6.5 (Carr and Simpson, 1978; Bhattacharyya et al., 1991), however, the vast majority of the deficit must be in the neuronal population in early precursor cells, neuroblasts, or postmitotic neurons. Thus, these data indicate that a functional trkC receptor is required for early differentiation of cells within the DRG, before the onset of postmitotic neuronal cell death.

\section{Immature DRG neurons express functional trkC receptors}

TrkC is known to have several isoforms, only some of which include a kinase domain (Lamballe et al., 1993; Tsoulfas et al., 1993; Valenzuela et al., 1993; Garner and Large, 1994), which would not be distinguished using our antibody to the extracellular domain. To assess more directly the functional significance of this early, widespread expression of trkC in the developing DRG (Fig. $3 E$ ), neurons from E4.5 DRG were dissociated and cultured in the presence or absence of NT-3. Under "impoverished" conditions, that is, in the absence of serum and added growth factors or supplements (see Materials and Methods), almost all of these 

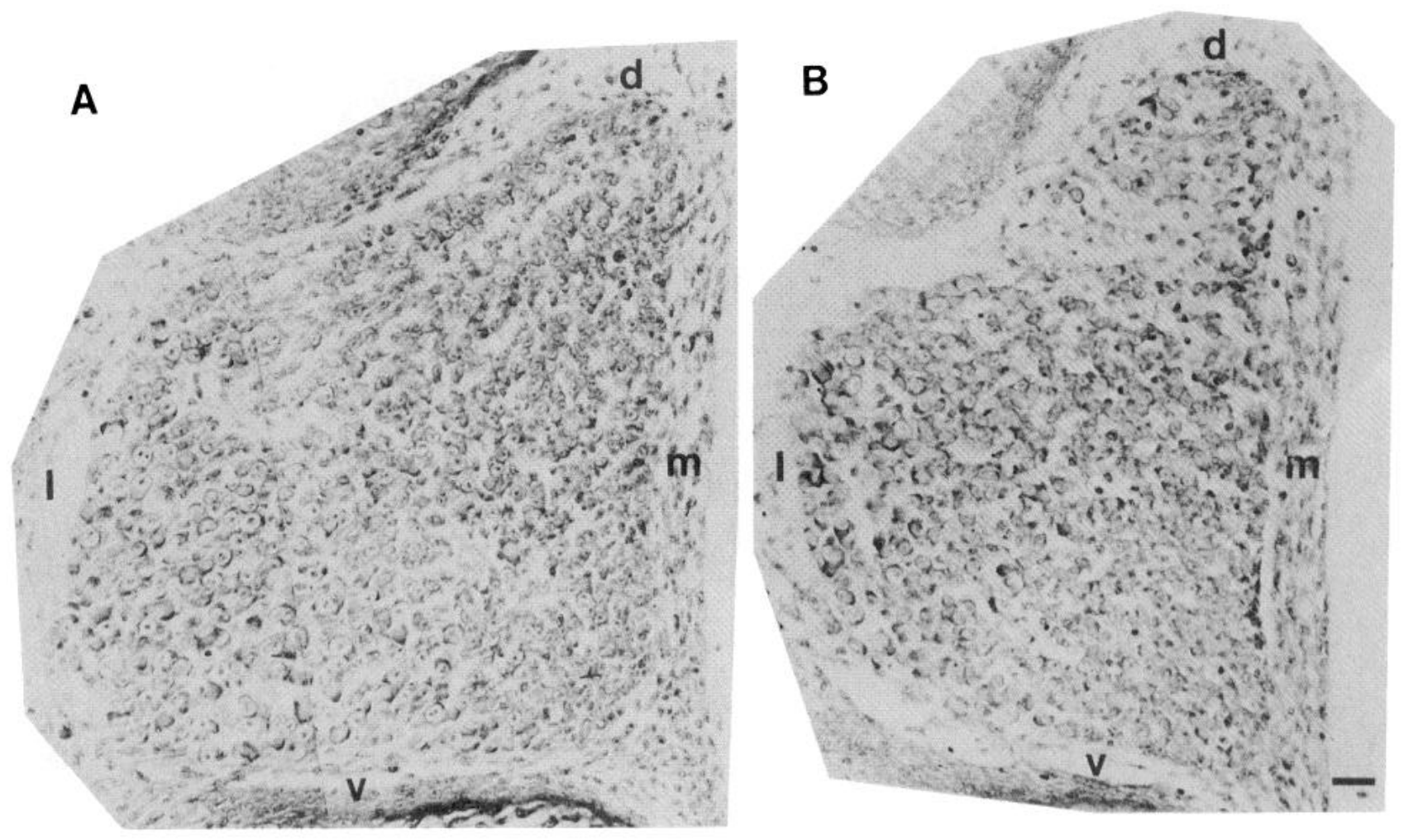

Figure 4. Sections through brachial ganglion 14 at St.31/32 after incubation with $(A)$ control Fab fragments or $(B)$ anti-trkC $(C T C)$ Fab fragments. Note that the section in $B$ is smaller than that in $A$ and contains many more pyknotic nuclei and fewer larger-diameter neurons. $d$, Dorsal; $v$, ventral; $l$, lateral; $m$, medial. Scale bar, $20 \mu \mathrm{m}$.

cells died after 24 hr in vitro. The majority of them, however, could be rescued by culturing in the presence of NT-3 $(10 \mathrm{ng} / \mathrm{ml})$, indicating a potent responsiveness to this neurotrophin (Fig. $5 A$ ). To determine whether this response to NT-3 was mediated by trkC, we replaced NT-3 with anti-trkC IgG as a receptor agonist and observed that the CTC IgG was approximately as effective as NT-3 in promoting the survival and outgrowth of these young DRG neurons. Previous work has documented an early response of DRG neuronal precursor cells to NT-3 (Wright et al., 1992; Memberg and Hall, 1995). These results suggested that NT-3 promotes the proliferation and/or differentiation of these precursor cells. Because we counted cells only at the end of the $24 \mathrm{hr}$ culture period, we have not yet determined whether the major effect of trkC receptor activation results from promotion of survival of the neuroblasts or precursor cells, promotion of precursor cell differentiation into neurons, or survival of the early postmitotic cells that differentiate in these cultures.

To determine whether other neurotrophins were as effective as NT-3 in promoting survival of immature DRG neurons, we compared the relative abilities of NGF, BDNF, and NT-3 in E4.5 DRG neuronal survival assays in vitro. As noted above, in such relatively "impoverished" culture conditions, most of the neurons die in the absence of exogenously supplied neurotrophin. Each neurotrophin promoted neuronal survival and differentiation in these conditions (Fig. 5B). NGF and BDNF, however, supported only $\sim 50$ and $60 \%$ of the neuronal numbers supported by NT-3. In wells receiving a combination of all three neurotrophins, no significant difference was found among the number of neurons in those wells, compared with wells treated with only NT-3. These results argue that the vast majority of cells expressing trkA or trkB also express trkC at this stage. Again, given the multitude of reported effects of NT-3 and BDNF on immature DRG cells in vitro (Wright et al., 1992; Memberg and Hall, 1995), these data do not distinguish between possible mechanisms underlying the increased number of neurons present in neurotrophin-treated wells, but they do demonstrate clearly the potent role of NT-3 on these cells.

\section{DISCUSSION}

Our primary goal in this study was to examine the function of trkC in the development of the DRG. To this end, we have generated an antibody that interferes with the ability of trkC to interact with its ligand(s). Using it for immunocytochemistry, we found that trkC is expressed on a subset of neural crest cells and subsequently becomes prominently expressed by the vast majority of cells comprising the immature DRG. This early widespread expression of trkC in the DRG changes dramatically during the second week of embryonic development when the receptor becomes restricted primarily to larger-diameter neurons in the $\mathrm{VL}$ region of the ganglion. These data indicate that most and perhaps all DRG neurons and/or precursor cells express trkC at an early stage of development, raising the possibility that NT-3 plays an essential role in their early differentiation.

To assess the functions of trkC during DRG genesis and maturation, CTC Fabs were injected into young chick embryos from St.18 to St.31. As summarized in Figure 6, these time points were chosen to span the period encompassing the end of neural crest migration and their condensation into nascent DRG, the proliferation and maturation of precursor cells into mature, postmitotic neurons, and finally, the bulk of target-mediated cell death for the 

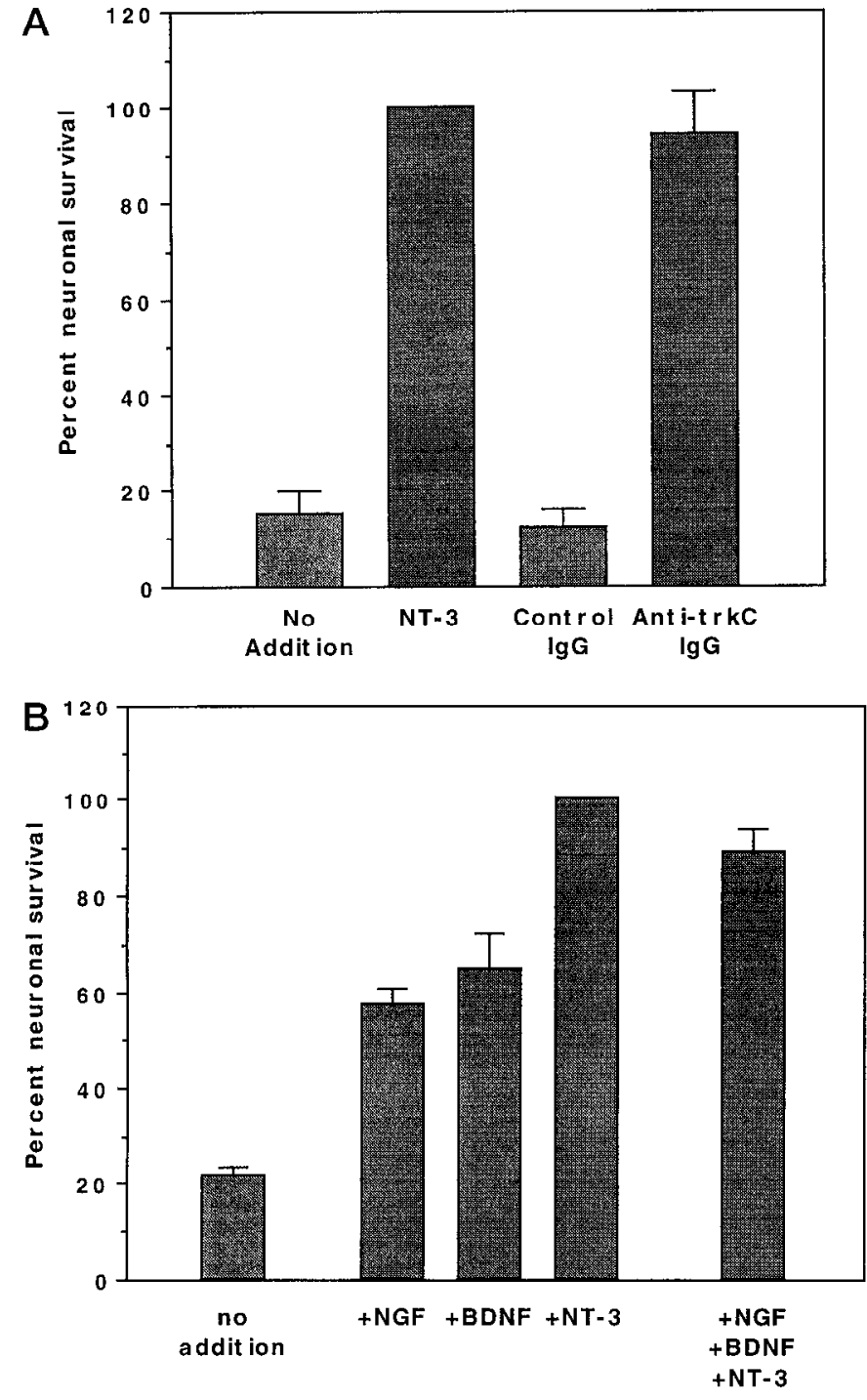

Figure 5. $A$, Both NT-3 and anti-TrkC bivalent IgG can promote the survival and outgrowth of E4.5 (St.25) DRG neurons in vitro. Neurons from DRG of E4.5 embryos were cultured in vitro alone or in the presence of either NT-3 $(10 \mathrm{ng} / \mathrm{ml})$ or anti-trkC $\operatorname{lgG}(50 \mu \mathrm{g} / \mathrm{ml})$ or nonimmune rabbit IgG $(50 \mu \mathrm{g} / \mathrm{ml})$. After $24 \mathrm{hr}$, the number of surviving ncurons with neurites was determined. The data are expressed as the mean (relative to NT-3) \pm SEM of duplicate cultures from three separate experiments. $B$, At E4.5, when compared with BDNF or NGF, NT-3 is the most effective neurotrophin for promotion of survival and outgrowth of DRG neurons. The number of neurons rescued by combining all three neurotrophins does not surpass that supported by NT-3 alone. Neurons from DRG of E4.5 embryos were cultured for $24 \mathrm{hr}$ in vitro, alone or in the presence of NGF, BDNF, or NT-3 (all at $10 \mathrm{ng} / \mathrm{ml}$ ) or a combination of all three. Data are expressed as the mean number of neurons with neurites (relative to NT-3) \pm SEM for triplicate cultures from two experiments. The mean number of surviving cells in each treatment was compared in a two-way ANOVA and by the Student-Newman-Keuls method. The means from the NT-3 treatment alone were not found to be significantly different from the means of wells treated with all three neurotrophins; however, the means of both of those groups (NT-3 alone and combined neurotrophins) were found to be significantly different from the means of BDNF, NGF, or untreated wells $(\alpha=0.05)$.

VL neurons in the DRG. Our results show that such injections in ovo result in a reduction of almost $50 \%$ in the number of brachial DRG sensory neurons. Half of this decrease in cell number occurred before the classical programmed cell death period.
These results suggest that either sensory neuron progenitor cells or a significant fraction of immature neurons, or both, express trkC, but later they downregulate the expression of this receptor and upregulate expression of trkA, the NGF receptor.

The reduction in neuronal survival induced by anti-trkC Fabs $(47 \%)$ is similar to the reduction in DRG neurons measured by Gaese et al. (1994) after injection of a blocking antibody to NT3 in ovo (36\%). These data are consistent with the finding that to date, NT-3 is the only known ligand for trkC (Lamballe et al., 1991; Ip et al., 1993). The postmitotic cell death period in the brachial region begins between E4 and E5 (Fig. 6) (Carr and Simpson, 1978; Hamburger et al., 1981), peaks between E5 and E6 for the VL population, and then persists at a lower rate until E10/11 (summarized in Fig. 6). Interestingly, we found that by analyzing cell numbers at an earlier time point (at E5 for trkC), a significant reduction in DRG cell numbers could already be detected. Thus, both sets of results point to an early role for trkC/NT-3 interactions in the developing DRG, before the period of target-mediated cell death (Coggeshall et al., 1994).

Our results are similar to observations in mice homozygous for a mutation in the NT-3 gene (Ernfors et al., 1994; Farinas et al., 1994; Tessarollo et al., 1994) in which there is a dramatic deficit of DRG neurons $(50-80 \%)$. Mice lacking the kinase domain, but not the extracellular domain of trkC, exhibit a loss of only $\sim 20 \%$ of DRG neurons (Klein et al., 1994). One possible reason for the stronger effect of antibody-mediated trkC inhibition in the chick compared with targeted mutagenesis in the mouse could be that our antibody, which is directed against the extracellular domain of trkC, should bind all isoforms of the receptor. Although our understanding of the functions of nonkinase-containing isoforms of trkC is limited, evidence has been presented for possible signaling through one of the truncated isoforms of trkB (Radeke et al., 1994). It will be interesting to compare the phenotype of mice deficient in all isoforms of trkC with that of mice deficient in only kinase-containing isoforms.

At E7/E7.5, we found, in agreement with Oakley et al. (1995), that the major cell type depleted after antibody injection (in their case, an anti-NT-3 antibody) was the large-diameter, VL-located subpopulation of neurons. Their work and other studies have shown that the Ia muscle afferents are derived from this subpopulation (Hory-Lee et al., 1993). Our analysis of trkC receptor expression (Fig. 3), as well as in situ trkC mRNA localization data (Williams et al., 1993; Kahane and Kalcheim, 1994; Zhang et al., 1994; Oakley et al., 1995), demonstrates that during the second week of embryonic development, the neurons that strongly express trkC are primarily large-diameter neurons located in the VL sector of the avian DRG. Thus, our finding of a heavy cell loss in the VL subpopulation at E7/7.5 is entirely consistent with this pattern of expression.

Because the blocking anti-trkC Fabs were injected directly into the base of the limb bud, the most likely cause of neuronal death is the peripheral blockade of trkC receptors that are prominently expressed on sensory axons as they project toward their targets (Plouffe et al., 1995; our unpublished observations). Several studies have shown that NT-3 is produced in developing limb buds (Henderson et al., 1993) and spinal cord (Pinco et al., 1993; Elkabes et al., 1994) as well as in the DRG itself (Schecterson and Bothwell, 1992; Pinco et al., 1993; Elkabes et al., 1994; Zhang et al., 1994). Thus, even before the onset of axonogenesis, the differentiating neurons in the DRG could presumably be exposed to NT-3 from one or more of those sources. The presence of NT-3 in the DRG itself suggests the intriguing possibility that it sup- 


\section{Successive stages of brachial dorsal root ganglia differentiation*}

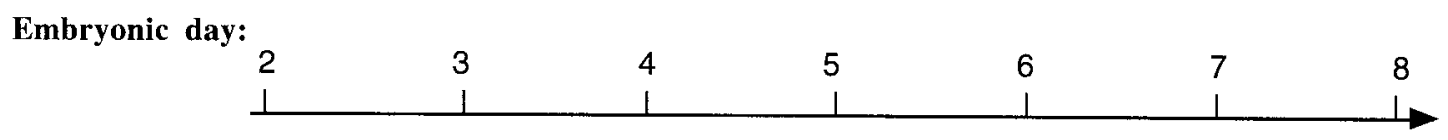

TrkC expression

Incubation with anti-trkC Fabs

Neural crest coalescence and DRG formation\#

Neurogenesis*

peak*

Neuronal Degeneration*

$\operatorname{peak}^{*}(\mathrm{VL})$

* Carr and Simpson, 1978

\#Lallier and Bronner-Fraser, 1988

Figure 6. Summary time-scale depicting the major events in the development of the DRG.

ports at lcast some of those neurons in an autocrine or paracrine loop, which was blocked by our antibody injections. Others have found evidence that BDNF functions in an autocrine manner to support the survival of DRG neurons (Acheson et al., 1995).

In addition to the deficit induced in the VL DRG subpopulation by the CTC Fabs, we also measured a smaller deficit in the small-diameter DM subgroup. During the period of postmitotic, naturally occurring cell death, the vast majority of these neurons express trkA (Lefcort et al., 1993, 1994) and depend on NGF for survival (Hory-Lee et al., 1993; Lopresti and Scott, 1994). What could account for their loss? One possibility is that DM cells are lost indirectly as a result of the considerable depletion of the VL cells (Silos-Santiago et al., 1995). Experiments will have to be conducted to test this hypothesis directly. Another possibility would be cross-reactivity of the anti-trkC antibody with trkA; however, neither our biochemical nor our functional characterizations of the antibody support that hypothesis (Figs. 1, 2B). Rather, our data are consistent with the idea that at some earlier stage in their differentiation, some if not all of these neurons go through a period of trkC expression before or while maturing into trkA-positive, NGF-dependent neurons, and/or alternatively, there exists a population of progenitor cells that are trkC-positive and depend on NT-3. This switch in trk receptor expression is similar to that observed in trigeminal sensory neurons (Buchman and Davies, 1993) and by sympathetic neuroblasts (Birren et al., 1993; DiCicco-Bloom et al., 1993).

Because the majority of the neurons in the DRG at E4-6 express trkC (Table 1, Fig. 3) (Williams et al., 1993; Kahane and Kalcheim, 1994; Zhang et al., 1994) and this period corresponds to the peak in neurogenesis in the DRG (Carr and Simpson, 1978), the likelihood of receptor switching and/or coexpression of more than one trk family member is high. Further evidence for receptor coexpression comes from our finding a lack of additive effect of combined neurotrophin application (Fig. $5 B$ ) to young (E4.5) DRG neurons in vitro, although all three neurotrophins individually could support a percentage of the cells. Of the three neurotrophins, NT-3 was clearly the most potent; furthermore, its effects could be mimicked completely by culturing in the presence of the activating bivalent anti-trkC IgG (Fig. $5 A$ ). Thus, together these dala are consistent will our in ovo results and support the idea that the early prominent expression of functional isoforms of trkC at E4.5 support neuronal survival and outgrowth.

In summary, our results point to a significant role for trkC throughout the period of DRG development. With an antibody specific for the extracellular domain of trkC, we demonstrate, beginning with expression on a discrete subset of neural crest cells, early and broad expression of trkC protein in the developing DRG. Interestingly, during the peak period of proliferation, neurogenesis, and differentiation in the $\mathrm{DRG}$, we show that trkC protein is expressed by the vast majority of cells in the immature DRG. Inhibition of this receptor in ovo, beginning during the process of neural crest migration and continuing through the periods of neurogenesis, differentiation, and programmed cell death, results in a severe deficit in DRG neuronal numbers. Half of this deficit occurred before the naturally occurring, targetmediated cell death period. Given that NT-3 enhances neural crest and DRG precursor cell proliferation (Kalcheim et al., 1992; Memberg and Hall, 1995) and differentiation (Wright et al., 1992; Chalazonitis et al., 1994; Davies, 1994) in vitro, further study will be required to determine more rigorously the stages of development at which NT-3-trkC interactions are essential: proliferation of the crest cells giving rise to the DRG, survival of neuroblasts or neuronal precursor cells, or the promotion of their differentiation into mature neurons. 


\section{REFERENCES}

Acheson A, Conover JC, Fandl JP, DeChyiara TM, Russell M, Thadani A, Squinto SP, Yancopoulos GD, Lindsay RM (1995) A BDNF autocrine loop in adult sensory neurons prevents cell death. Nature 374:450-453.

Bhattacharyya A, Frank E, Ratner N, Brackenbury R (1991) Po is an early marker of the Schwann cell lineage in chickens. Neuron 7:831-844.

Birren SJ, Lo L, Anderson DJ (1993) Sympathetic neuroblasts undergo a developmental switch in trophic dependence. Development 119:597-610.

Bothwell M (1995) Functional interactions of neurotrophins and neurotrophin receptors. Annu Rev Neurosci 18:223-253.

Bronner-Fraser M (1994) Environmental influences on neural crest migration. J Neurobiol 24:233-247.

Buchman VL, Davies AM (1993) Different neurotrophins are expressed and act in a developmental sequence to promote the survival of embryonic sensory neurons. Development 118:989-1001.

Carr VM, Simpson SB (1978) Proliferative and degenerative events in the early development of chick dorsal root ganglia. J Comp Neurol 182:727-740.

Chalazonitis A, Rothman TP, Chen J, Lamballe F, Barbacid M, Gershon MD (1994) NT-3 induces neural crest-derived cells from fetal rat gut to develop in vitro as neurons or glia. J Neurosci 14:6571-6584.

Clary DO, Weskamp G, Austin LAR, Reichardt LF (1994) TrkA crosslinking mimics neuronal responses to nerve growth factor. Mol Biol Cell $5: 549-563$

Coggeshall RE, Pover CM, Fitzgerald M (1994) Dorsal root ganglion cell death and surviving cell numbers in relation to the development of sensory innervation in the rat hindlimb. Dev Brain Res 82:193-212.

Davies AM (1994) The role of neurotrophins in the developing nervous system. J Neurobiol 25:1334-1348.

DiCicco-Bloom E, Friedman WJ, Black IB (1993) NT3 stimulates sympathetic neuroblast proliferation by promoting precursor survival. Neuron 11:1101-1111.

Elkabes S, Dreyfus C, Schaar D, Black IB (1994) Embryonic sensory development: local expression of NT-3 and target expression of nerve growth factor. J Comp Neurol 341:204-213.

Ernfors P, Lee KF, Kucera J, Jaenisch R (1994) Lack of NT3 leads to deficiencies in the peripheral nervous system and loss of limb proprioceptive afferents. Cell 77:503-512.

Ernsberger U, Rohrer H (1988) Neuronal precursor cells in chick dorsal root ganglia: differentiation and survival in vitro. Dev Biol 126:420-432.

Evan GI, Lewis GK, Ramsay G, Bishop JM (1985) Isolation of monoclonal antibodies specific for human c-myc proto-oncogene product. Mol Cell Biol 5:3610-3616.

Farinas I, Jones K, Backus C, Wang X, Reichardt LF (1994) Severe sensory and sympathetic deficits in mice lacking NT3. Nature 369:658-661.

Gaese F, Kolbeck R, Barde YA (1994) Sensory ganglia require neurotrophin-3 early in development. Development 120:1613-1619.

Garner AS, Large TH (1994) Isoforms of the avian trkC receptor: a novel kinase insertion dissociates transformation and process outgrowth from survival. Ncuron 13:457-472.

Hamburger V, Brunso-Bechtold JK, Yip JW (1981) Neuronal death in the spinal ganglia of the chick embryo and its reduction by nerve growth factor. J Neurosci 1:60-72.

Harlow E, Lane D (1988) Antibodies: a laboratory manual. Cold Spring Harbor, NY: Cold Spring Harbor Laboratory.

Henderson CE, Camu W, Mettling C, Gouin A, Poulsen-K, Karihaloo M, Rullamas J, Evans T, McMahon SB, Armanini MP (1993) Neurotrophins promote motor neuron survival and are present in embryonic limb bud. Nature 363:213-214.

Hory-Lee F, Russell M, Lindsay RM, Frank E (1993) NT3 supports the survival of developing muscle sensory neurons in culture. Proc Natl Acad Sci USA 90:2613-2617.

Ip NY, Stitt TN, Tapley P, Klein R, Glass DJ, Fandl J, Greene LA, Barbacid M, Yancopoulos GD (1993) Similarities and differences in the way neurotrophins interact with the trk receptors in neuronal and nonneuronal cells. Neuron 10:137-149.

Kahane N, Kalcheim C (1994) Expression of trkC receptor mRNA during development of the avian nervous system. J Neurobiol 25:571-584.

Kalcheim C, Carmeli D, Rosenthal A (1992) NT3 is a mitogen for cultured neural crest cells. Proc Natl Acad Sci USA 89:1661-1665.
Klein R, Silos-Santiago 1, Smeyne RJ, Lira SA, Brambilla R, Bryant S, Zhang L, Snider WD, Barbacid M (1994) Disruption of the neurotrophin-3 receptor gene trkC eliminates Ia muscle afferents and results in abnormal movements. Nature 368:249-251.

Lallier TE, Bronner-Fraser M (1988) A spatial and temporal analysis of dorsal root and sympathetic ganglion formation in the avian embryo. Dev Biol 127:99-112.

Lamballe F, Klein R, Barbacid M (1991) TrkC, a new member of the trk family of tyrosine protein kinases is a receptor for neurotrophin-3 Cell 66:967-979.

Lamballe F, Tapley P, Barbacid M (1993) TrkC encodes multiple neurotrophin-3 receptors with distinct biological properties and substrate specificities. EMBO J 12:3083-3094.

Lefcort F, Clary DO, Sehgal R, Rcichardt LF (1994) Blocking antibodies to the extracellular domain of avian trkC significantly reduce the size of brachial DRG in vivo. Soc Neurosci Abstr 20:238.

Lefcort F, Reichardt LF, Clary DO (1993) Bivalent antibodies to trk receptors promote neuronal survival and outgrowth in the absence of neurotrophins. American Society for Cell Biology Abstr. Addendum: special poster session.

Lopresti P, Scott SA (1994) Target specificity and size of avian sensory neurons supported in vitro by NGF, BDNF and NT-3. J Neurobiol 25:1613-1624.

Memberg SP, Hall AK (1995) Proliferation, differentiation and survival of rat sensory neuron precursors in vitro require specific trophic facturs. Mol Cell Neurosci 6:323-335.

Oakley RA, Garner AS, Large TH, Frank E (1995) Muscte sensory neurons require N' -3 trom peripheral tissues during the period of normal cell death. Development 121:1341-1350.

Pinco O, Carmeli C, Rosenthal A, Kalcheim C (1993) Neurotrophin-3 affects proliferation and differentiation of distinct neural crest cells and is present in the early neural tube of avian embryos. J Neurobiol 24:1626-1641.

Plouffe PJ, Oakley RA, Lefcort FB, Clary DO, Reichardt LF, Frank E (1995) Expression of trkC in cutaneous nerves during embryogenesis. Soc Neurosci Abstr 21:33.

Radeke M, Baxter G, Kuo R, Medina-Selby A, Valenzuela DCP, Feinstein SC (1994) Signal transduction by the truncated trkB isoform trkBT1. Soc Neurosci Abstr 20:37.

Schecterson LC, Bothwell M (1992) Novel roles for neurotrophins are suggested by BDNF and NT-3 mRNA expression in developing neurons. Neuron 9:449-463.

Scott SA (1992) Sensory neurons: diversity development and plasticity. New York: Oxford UP.

Silos-Santiago I, Molliver DC, Ozaki S, Smeyne RJ, Fagan A, Barbacid M, Snider WD (1995) Non-TrkA expressing small DRG neurons are lost in TrkA-deficient mice. J Neurosci 15:5929-5942.

Snider WD (1994) Functions of the neurotrophins during nervous system development: what the knockouts are teaching us. Cell 77:627-638.

Tessarollo L, Vogel KS, Palko ME, Reid SW, Parada LF (1994) Targeted mutation in the neurotrophin-3 gene results in loss of muscle sensory neurons. Proc Natl Acad Sci USA 91:11844-11848.

Tosney KW (1978) The early migration of ncural crest cells in the trunk region of the avian embryo: an electron microscopic study. Dev Biol 62:815-830.

Tsoulfas P, Soppet D, Escandon E, Tessarollo L, Mendozi-Ramirez JL, Rosenthal A, Nikolics K, Parada L (1993) The rat trkC locus cncodes multiple neurogenic receptors that exhibit differential response to NT-3 in PC12 cells. Neuron 10:975-990.

Valenzuela DM, Maisonpierre PC, Glass DJ, Rojas E, Nunez L, Kong Y, Gies DR, Stitt TN, Ip NY, Yancopoulos GD (1993) Alternative forms of rat $\mathrm{TrkC}$ with different functional capabilities. Neuron 10:963-974.

Williams R, Backstrom A, Ebendal T, Hallbook F (1993) Molecular cloning and cellular localization of trkC in the chicken embryo. Dev Brain Res 75:235-252.

Wright EM, Vogel K, Davies AM (1992) Neurotrophic factors promote the maturation of developing sensory neurons before they become dependent on these factors for survival. Neuron 9:139-150.

Zhang D, Lihua Y, Bernd P (1994) Expression of trk and neurotrophin mRNA in dorsal root and sympathetic ganglia of the quail during development. J Neurobiol 25:1517-1532. 